\title{
COMMON TRUST FUND LEGISLATION
}

\author{
Robert W. Bogue*
}

The movement to enact legislation authorizing the creation of common trust funds is of recent origin. That movement was given momentum in 1936 with the passage of the Federal Revenue Act $^{1}$ which exempted common trust funds from taxation as corporations. As a result, it is expected that in 1939 when most of the state legislatures again convene many states will give legislative sanction to the establishment of common trust funds. At the present time eight states have enacted such statutes. ${ }^{2}$ All but three of the statutes antedate the passage of the Federal Revenue Act. Ohio, far ahead of the other states, passed its act in Igrg. Vermont and Pennsylvania enacted enabling legislation in r933. Delaware and Oregon followed in the next general assembly year, I935. In I937 Indiana, Minnesota, and New York passed similar acts. Pennsylvania in that year enacted another statute which is devoted to participating mortgages, but which is in terms broad enough to include common trust funds.

The statutes which have been passed fall between extremes set by the statutes of Ohio and New York. The Ohio act is brief and general, merely authorizing the establishment of common trust funds. At the other extreme the New York statute not only provides in considerable detail rules for the formation and control of common trust funds, but also directs their supplementation with regulations by the New York State Banking Board. ${ }^{3}$ The remaining statutes provide requirements and restrictions, but do not attempt to enact a complete scheme.

Other articles in this symposium deal with problems of policy and practice in the regulation and operation of common trust funds. ${ }^{4}$ Accordingly the purpose of this article has been restricted to the comparative analysis of the terms of the eight enabling acts. Because of its comprehensive character the New York act has been used as a point of departure in the sections which follow. Subsequent references to the state statutes will not be accompanied by citations except for the New York, Indiana, and 1933 Pennsylvania acts which alone are divided into sections.

- A.B., I936, University of Wisconsin. Now a second-year student in the Duke University School of Law. Member of the Editorial Board of the Duke Bar Association lournal.

${ }^{1} 49$ STAT. 1708, 26 U. S. C. A. \$169 (Supp. 1936).

${ }^{2}$ Ohro Gen. Code Awn. (Page, Supp. 1935) \$7ro-r64; Vt. Pub. Laws (1933) \$68r6; PA. Stat. (Purdon, 1937) tit. 7, \$819-1109, as amended by Pa. Laws 1937, no. 351; PA. Stat. (Purdon, 1937) tit. 20, §801; Del. Laws 1935, c. 230; Ind. Acts 1937, c. 33, \$20; Minn. Laws 1937, c. I74; N. Y. Laws r937, c. 687 .

N. Y. Banking Lsw, \$ro-c(II).

'Capron, Federal Reserve Board Regulations for Common Trust Funds, infra p. 439; Ward, Problems in the Administration of Common Trust Funds, infra p. 453. 
Legal Structure

Common trust funds have in the past taken the form of a pool, trust, or corporation." The pool plan contemplates an outright undivided legal ownership of assets in the common fund by each participating trust. The trust type of common fund requires the trust company to make a declaration of trust of the common fund assets under which the trust company holds legal title to the whole fund and the equitable title of the interests as trustee of the participating estates, leaving the beneficiaries an equitable interest in an equitable interest. The corporate form of common fund employs the formation of a separate corporation to hold legal title to the assets. The participating trusts hold shares of stock in the incorporated fund.

The New York act provides: "Ownership of the individual assets and investments of the common trust fund shall be in the trust company as trustee of such fund." Such a provision seems to require the establishment of a legal structure of the trust type. Concurring with New York is Vermont providing: "A trust company. may create a trust investment account to be known as its associated investment account to which may be intrusted for investment the whole or any part of the funds of trusts permissible to be associated. An individual trust whose funds are thus associated shall at all times be considered the equitable owner of its pro rata share." The Pennsylvania statute, first enacted, is devoted to authorization of common trust funds established by a trust company, and limits the fund to a trust form of legal structure in this language: "Interests in such pool or fund . . . shall be held solely by the bank and trust company, or the trust company, as fiduciary, and the equitable interest owned solely by the estates of which such bank and trust company, or trust company is fiduciary." The more recent Pennsylvania statute is couched in these terms: ". . . such fractional interests being apportioned among estates of which the person or sorporation creating such fractional undivided interests is the fiduciary." The absence of the characterizing ihrase "equitable interests" from this act would seem to permit, if not to compel, the pool structure. The Oregon statute is of a similar type: "A trust company ... may apportion any part interest therein to any of its trusts." The statute of Minnesota provides: "[The trust company] may invest in fractional parts of, as well as in whole, securities, or may commingle funds for investments, all of the fractional parts of such securities, or the whole of the funds so commingled shall be owned and held by such trust company in its several trust capacities." Such language points to the pool rather than the trust type of legal structure. The remaining states make no provision restricting the fund to any of the three categories.

${ }^{5}$ Smith, Commingled Trust Funds as a New Advance in Fiduciary Service (1933) 54 Trust Companies, 183; Peter, Commingled Funds-An Analysis, 2 Prentice-Harl Trust Service, qroo46 (r937); Barclay, Valuable Experience with Commingled Funds for Trust Estates (1933) 56 Trust Companies, 183 ; McWhinney, Results from a Questionnaire on Commingling of Trust Funds (193I) 52 id. 333; Common Trust Fund Problems Require Further Service, Fenninger Reports, Enabling Legislation Needed (1935) 60 id. I44 (1935); Note (1937) Cor. L. Rev. 1384 .

-N. Y. Banking Law \$100-c(2).

'PA. Stat. (Purdon, r937) tit. 7, \$819-1 rog(A). 


\section{Trusts Eligible to Participate}

New York expressly prohibits the investment of funds from a trust revocable by the grantor, one not having a substantial adverse interest in the disposition of income or principal, or by such person in conjunction with the grantor. ${ }^{8}$ This precaution, adopted in no other state, apparently intended to prevent "runs" in periods of market depression perpetrated by persons who were using the fund as a subterfuge for investment purposes, has proved in the past to have been unnecessary because the feared "runs" failed to materialize.9

Only New York provides that except where the instrument forbids, permission to invest in a common fund has retrospective application. The act extends the use of common trust funds to those funds where there is a fiduciary relationship "arising before or after the passing of this act."10 In those states which provide the common fund as another legal investment, namely, Pennsylvania (second statute), Delaware, Oregon, and Indiana, restrospective application may be expected by analogy to any other change in the legal list which has such effect. Since one of the principal objections to relying on authorizations in the trust instruments to invest in common funds is the fact that this will not aid existing trusts, the importance of providing for retrospective application is evident.

\section{THE TrusteE}

Alone among the acts under consideration, the second Pennsylvania statute allows a personal trustee to set up a common fund. The prior Pennsylvania statute ${ }^{11}$ limits this power to corporate trustees, as do the statutes of the other states. Because the problems incident to the administration of numerous small trust funds arise primarily among corporate trustees such a limitation is to be expected.

The New York ${ }^{12}$ and Minnesota acts both allow a fund of which the trust company is co-trustee to be invested in a common trust fund. The Indiana statute would apparently require the trust company to be sole trustee of the participating estates. It provides: "nor shall any ownership of any part of said fund nor any interest therein be acquired by any person other than the bank or trust company in its fiduciary capacity." ${ }^{3}$ Delaware adopts somewhat similar language: "it shall not be permitted that any such fractional interests shall at any time be owned by any other than such bank or trust company acting in a fiduciary capacity." The language of both the Indiana and Delaware statutes, while apparently not aimed at eliminating the possibility of a co-trustee, would seem broad enough to accomplish that end.

The provision in the Federal Revenue Act that the common fund "be exclusively for the collective investment of moneys contributed thereto by the bank in its capacity

\footnotetext{
${ }^{8}$ N. Y. BANRING LAW \$roo-c(r).

'Capron, The Federal Reserve Board Regulations of Common Trust Funds, infra, f. 447.

${ }^{10}$ N. Y. BANRING LAW \$100-c(I).

${ }^{11}$ Pa. Stat. (Purdon, I937) tit. 7, \$8rg-Irog(A); N. Y. Banking Law \$ro0-c(I6); Ind. Acts r937, c. $33, \$ 20$.

${ }^{2}$ N. Y. Banking Law \$roo-c(1). $\quad{ }^{23}$ Ind. Acts 1937, c. $33, \$ 20(5)$.
} 
as trustee, executor, administrator or guardian,"14 is somewhat ambiguous. The purpose of the provision is to guarantee that the funds will not be used for nonfiduciary purposes, and a construction which would expose the whole fund to taxation because the trust company was co-trustee of one participating trust would be a strained one.

No other statutes contain pertinent provisions either way, with the exception of clauses vesting exclusive control to the trust company. Both New York ${ }^{25}$ and Delaware have such provisions. Because unity of control is vital to managerial efficiency and responsibility, and because the Federal Reserve Board regulations ${ }^{16}$ require such exclusive control, a construction of the other statutes to reach that end seems desirable.

This vesting of exclusive control over common trust funds in the corporate trustees creating them would result in an improper delegation of authority by depriving individual co-trustees of their discretionary powers with respect to investments in the common fund. Such a delegation would normally constitute a breach of trust. ${ }^{17}$ Consequently in those states where no express provision is made for co-trustees the statute may be construed so as to preclude participation of trust estates which are held by more than one trustee. Where, however, the statute provides expressly, as in New York and Minnesota, or by implication, as may prove to be the case in other states, that estates in which there are co-trustees may participate in the fund, then it would appear that the statute has to this extent changed the common law rule as to delegation. Yet even though the co-trustee has not improperly delegated his powers by authorizing investment in the fund, the question remains what liability he is subject to for subsequent investment losses. An inactive trustee is usually held to a duty of exercising a reasonable degree of diligence in supervision over the management of the trust estate, ${ }^{18}$ and, if, in the exercise of such diligence, a co-trustee were to learn of mismanagement in a common fund, he would be under a duty to act for the protection of the estate. New York facilitates such action by granting the cotrustee power to compel withdrawal upon presentation to the trust company of written notice. ${ }^{19}$ In the absence of such a provision a co-trustee, by producing before the proper court evidence of improper management of the fund, could obtain a court order directing such withdrawal.$^{20}$ Legislative clarification of the problem seems needed.

1649 STat. I708, 26 U. S. C. A. \$169(a) (Supp. 1936).

${ }^{25}$ N. Y. Banking LAw \$100-c(2).

${ }^{30}$ The Federal Revenue Act provides that a trust company, if it desires tax immunity from the corparate tax, must comply with the Federal Reserve Board regulations. 49 STst. 1708, 26 U. S. C. A. $\$ 169$ (2) (Supp. 1936). Accordingly, the Federal Reserve Board last December issued the regulations. Fed. Res. Bd., Regulation F ("Trust Powers of National Banks"), \$17c.

${ }^{17} 3$ Bogert, Trusts AND Trustees (1935) $\$ 555$ et seq.

is Id. $\$ 587$.

${ }^{28}$ N. Y. BAnking Law \$100-c(I)(16).

${ }^{20} 3$ BOGERT, TRUSTS AND TrUstees (1935) $\$ \$ 19,522$. 


\section{The Fiductary Relationship}

The common fund does not serve the real purpose for which it was intended unless it is limited to funds held by the trust company in true fiduciary capacity. Otherwise it may easily become a mere investment trust. To guard against this danger seems to have been the purpose of the provisions of the Indiana and Delaware statutes, quoted in the preceding section, forbidding the acquisition by any persons other than the trust institution of interests in the fund, ${ }^{21}$ a requirement reinforced by the Federal Reserve Board Regulation that documents evidencing the interest be neither negotiable nor assignable. ${ }^{22}$ In other states reliance seems to have been placed on a requirement that the funds invested be held by the institution in a fiduciary capacity. But even where the trust company is thus restricted, a question arises as to what fiduciary capacities are included. Statutes with respect to these matters vary in their degree of explicitness.

The New York act provides that a common fund may be established: "wherever there is a fiduciary relationship," and includes for investment funds held by the trust company as administrator, executor, guardian of an infant or incompetent, and trustee under a living or testamentary trust. ${ }^{23}$ The recently issued Banking Board regulations supplement these restrictions, providing: "The operation of common trust funds for other than true fiduciary purposes is hereby prohibited."24 The Indiana act ${ }^{25}$ contains provisions similar to those in the New York act. Pennsylvania $^{26}$ and Delaware without specifying categories of funds held authorize the investment of funds held in a "fiduciary capacity," with Delaware adding, "other than merely as agent." The Vermont act contains a rather unusual provision that a trust company may associate for common investment the funds of "individual trusts held by it whether created by court order or otherwise." This in addition to funds held strictly as trustee would seem to include funds held as administrator or guardian. The statutes of Ohio and Minnesota allow the investment of money held "as trustee" and "in trust capacity" respectively. Rather than run the risk of a narrow interpretation of such provisions, it would seem advisable to adopt the wider provision used by New York. The Oregon statute provides that a trust company owning any part of certain specified investments may apportion any part interest therein "to its trusts."

\section{Self-Dealing by the Trust Company}

Although in the absence of express statutory provision the trust company will be subject to liability for self-dealing ${ }^{27}$ with respect to common trust funds, managerial facility has directed a relaxation in some instances. The New York act specifically provides that common fund assets shall be segregated, and that the trust company

\footnotetext{
2n Indiana also provides: "Participating interests shall not be transferable except to the bank or trust company as such fiduciary of another trust or estate." Ind. Acts 1937, c. 33, \$20(6).

${ }^{2}$ Fed. Res. Bd., Regulation F, $\$ I 7(a)$.

N. Y. Banking Law \$100-c(1)(16).

${ }^{*}$ N. Y. Banking Bd. Regulations, art. X(2).

${ }^{25}$ Ind. Acts 1937, c. $33, \$ 20(x)$.

* PA. Stat. (Purdon, I937) tit. 7, 5,819-I rog(A).

* 3 Bogert, Trusts and Trustees (1935) $\$ 543$.
} 
shall own no interest in the fund other than in its fiduciary capacity. ${ }^{28}$ Exception is made allowing the trust company to hold common trust moneys temporarily while awaiting investment or distribution; and to loan money to a liquidating account if necessary to preserve that account. ${ }^{29}$ The Delaware statute is in accord, providing: "it shall not be permitted that any fractional interests shall at any time be owned by other than such bank or trust company acting in a fiduciary capacity, and such bank or trust company temporarily for the purpose of making settlement of a fiduciary estate that has been terminated." The Pennsylvania act provides that, "in order to make distribution [an interest in the fund] may be sold by such bank and trust company or such trust company to another estate of which it is fiduciary or may be sold to its commercial department, which may in turn resell the same to another estate of which the bank is fiduciary." 30 . This act is objectionable because, while the opportunity for obtaining a self-interest in the fund is restricted, there is no limit to the length of time that interest may be held once it is acquired. Indiana apparently does not permit even temporary ownership in the funds by the trust company. The statute provides: "nor shall any ownership of any part of said fund nor any interest therein be acquired by any person other than the bank or trust company in its fiduciary capacity." 31 The Minnesota act contains the following restriction: "... and it [the trust company] shall be liable for the administration thereof in all respects as if separately invested." This broad provision would by application of general trust rules seem to prohibit self-dealing. The Oregon statute contains no express prohibition and permits one important form of self-dealing in the italicized clause following: ". . . may apportion any part interest therein to any of its trusts or may repurchase any such apportionment individually or in fiduciary capacity." Neither Ohio nor Vermont have included express provisions restraining or permitting such self-dealing. Inasmuch as the Federal Reserve Board regulations provide that the trust company shall hold none but a fiduciary interest in the common fund, except when compelled to so hold because of a creditor relationship and then only until the next valuation date, ${ }^{32}$ a trust company in either Oregon or Pennsylvania will find little comfort in the statutory permission to hold an interest if it desires immunity for its fund from the federal corporation tax.

One of the primary objections to common trust funds has been the fear that the trust company would use it as a dumping ground for its own shaky and depreciated securities. The disastrous use of the substitutionary type of participating mortgage certificates furnished an example of evils which arise from substitution. ${ }^{33}$ Consequently if the 1933 Pennsylvania act giving the bank or trust company the right to substitute another investment for a security in the fund if the substituted security is "at least of equal value,"34 is construed to permit the substitution of securities already held by the institution, then the provision is open to criticism. New York has

\footnotetext{
${ }^{25}$ N. Y. Banking LaW §100-c(4).

${ }^{s 0}$ PA. Stat. (Purdon, r937) tit. $7,8819-1109$ (A).

si Ind. Acts 1937, c. $33, \S 20(5)$.

Note (1934) Col. L. Rev. 663.
}

${ }^{20}$ Id. (1).

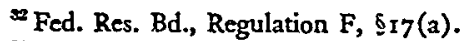

${ }^{3}$ PA. Stat. (Purdon, 1937) tit. 7, \$8rg-ring(c). 
adopted a more rigorous approach providing: "A trust company shall not invest any of its own funds in such a common trust fund nor shall any trust company purchase for such common fund any securities from itself or any affiliate."35

A New York prohibition against assessment of additional fees for maintaining a common trust fund ${ }^{36}$ is a further insurance that the institution will not be motivated by self-interest. The managerial economies anticipated in the establishment of a common fund afford justification for this restriction. Although no other state makes a similar provision, that result will be reached by a similar Federal Reserve Board regulation. ${ }^{37}$

\section{Evidencing Interests in the Fund}

The proportional interests held by the participating trusts, while satisfactorily recorded by modern bookkeeping methods of the trust company, often are evidenced by a document issued to each participant. The New York act in these terms: “. . . the company may apportion shares or interests to itself showing on its records every such share,"38 would apparently sanction either procedure. The Pennsylvania act has a more explicit provision: "The bank or trust company may issue a certificate of participation for every estate on behalf of which it owns a fractional undivided interest." ${ }^{39}$ The Oregon act provides that the: "records of the trust company shall at all times show every such participating interest." On the other hand the Indiana act requires certificates to be issued, providing: "participating interests shall be evidenced by certificates duly executed." 40 None of the other states deal with the subject.

In practice it has been thought advisable to make these participating interests units of uniform size, but no statute so requires. However, the New York Banking regulations provide that the original unit of participation shall be one hundred dollars or a multiple thereof. .1

\section{INVESTMENT RESTRICTIONS}

The New York act provides that the money held in the common fund may be invested by the trust company in any form of securities in which a savings bank may invest, subject to several exceptions of which only one, mortgages, is of major importance. ${ }^{42}$ No other state has imposed a like restriction. In the absence of special provision in the statute, the usual rules governing trust investment will apply to common funds: In Indiana, Delaware, Minnesota, Oregon and Pennsylvania, investments are to be governed by the statutory list of legals, ${ }^{43}$ unless the trust instrument provides other instructions.

Although it has been contended that $\$ 25,000$ is too low, ${ }^{44}$ the New York act and

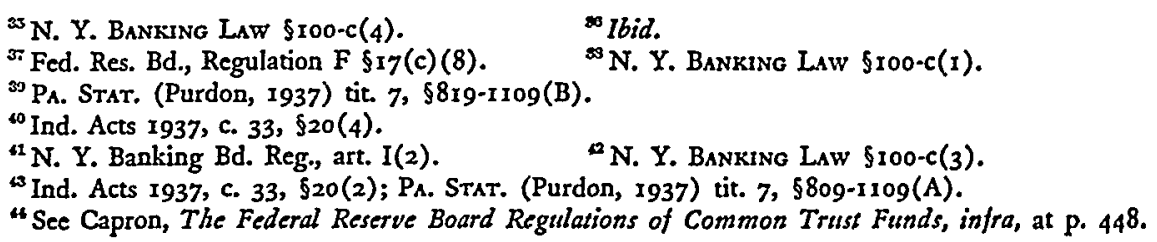


the Federal Reserve Board regulations both limit the investment of funds from any one estate to that figure. There is an ambiguity in the New York act: "In no event shall the net aggregate amount of any estate, trust, or fund invested in a common fünd exceed $\$ 25,000$ or such lesser sums as the Banking Board may fix." 45 Suppose $\$ 25,000$ is invested from one estate in each of two common funds established by the same institution. That this is not permissible is made clear in both the New York Banking Board regulations ${ }^{48}$ and the Federal Reserve Board regulations ${ }^{47}$ which specifically limit the investment to $\$ 25,000$ or $10 \%$ of the common fund, whichever is smaller, regardless of how many common trust funds maintained by the trust company may be used for investment of funds from one participating estate. Minnesota, the only other state providing such a limitation, has set the figure at $\$ 5,000$ unless express authority to invest in commingled funds is given to the trust company in the instrument creating the trust. The ambiguity discussed above does not appear.

\section{Valuation, Withdrawai, Liquidation, and SetTlement}

With respect to provisions under these heads, the New York Banking Board regulations and the Federal Reserve Board regulations alone are comprehensive. Since their provisions are discussed elsewhere in this symposium, they will be merely noted here.

The New York act permits investment or withdrawal only on a date fixed for valuation of the entire fund, such valuations to be made at least quarterly. ${ }^{48}$ Delaware requires a valuation upon the termination of each fiduciary estate owning a fractional interest, and so, apparently, does Indiana. ${ }^{49}$ The rule as set forth in the latter statutes, however burdensome in the administration of the fund, seems declaratory of the procedure which would be required in the absence of specific provisions to the contrary. "Market value" is the criterion for valuation employed in the statutes of Delaware, Indiana, and Vermont. In New York the method of valuation is prescribed in the Banking Board regulations. ${ }^{50}$

New York makes provision for a liquidating account in which investments becoming non-legal are to be segregated pending sale. ${ }^{51}$ This allows new estates to invest in the fund after some securities in its portfolio have fallen from the legal list, and also protects against the absorption of liquid assets through withdrawals from a partially frozen fund. Comparable requirements in the Federal Reserve Board regulations $\mathrm{s}^{52}$ afford protection in other states which have no provision dealing with the matter.

New York provides in detail special procedure for annual accountings and judicial settlements with respect to the fund as an entirety, notice being given to all interested persons. ${ }^{53}$ The absence of statutory provisions for this in other states would seem

\footnotetext{
¿ N. Y. Banking Law §I00-c(I).

${ }^{67}$ Fed. Res. Bd., Regulation F, $\$ 17$ (c) (5).

${ }^{60}$ Ind. Acts 1937, c. $33, \$ 20(6)$.

${ }^{8}$ N. Y. BANKING LaW \$roo-c(7).

${ }^{\infty}$ N. Y. BANking LAW \$roo-c(10)(11)(12).
}

${ }^{*} N$. Y. Banking Bd. Reg., art. III(2).

${ }^{4}$ N. Y. Banking LaW \$roo-c(6)(8).

${ }^{50}$ N. Y. Banking Bd. Reg., art. V.

2 Fed. Res. Bd., Regulation F, $\$$ I $(c)(6)$. 
to necessitate the incorporation of a scheme for settlement in the instrument establishing the fund if separate accountings for individual estates are to be avoided, although how complete a safeguard any method so prescribed would prove is open to some question. To insure accuracy of the account presented to the court the New York act provides that, on or before the return date of the notice, a bank examiner shall make an investigation of the common fund and present a certified report as to whether the condition of the common fund is correctly represented in the account. ${ }^{54}$

The Federal Reserve Board regulations undoubtedly will be an important influence in directing the form which subsequent state legislation will assume. Among the statutes already enacted there are apparently no affirmative requirements which prevent an institution from complying with the provisions of the Federal Reserve Board. ${ }^{55}$ In some instances the state regulations are more restrictive, in which case the state statute will control; in most cases the state regulations permit a broader degree of freedom, and the trust company to achieve desired tax immunity from the federal corporation tax will be compelled to comply with the Federal Reserve Board regulations through proper provisions in the trust instrument. With respect to still other questions the Federal Reserve Board is either silent, or merely states a requirement without elaboration. Solution of such problems, e.g., co-trustees, eligibility of revocable trusts, methods of valuation and settlement, is left to individual state statutes or to proper provisions in the trust instrument.

Adoption of a statute as inclusive as that of New York which sacrifices flexibility for certainty of control seems unnecessary in states which are not faced with the difficult problem of regulating many vast institutions. On the other hand, a statute as general and indefinite as that of Ohio seems inadvisable if the most successful use of the common trust fund is to be attained. Most desirable would be a statute which is general where the Federal Reserve Board regulations are specific, which provides supplementary rules where the Federal Reserve Board has indicated need for state action, and which vests in a state governing board power to keep the two in harmony.

sh Id. (13).

${ }^{\infty}$ A possible source of conflict lies in the provisions of the Delaware and Indiana laws providing for withdrawals at the termination of each participating trust. See p. 437 , stpra. 